\title{
Zika: an ongoing threat to women and infants
}

\author{
Zika: uma ameaça permanente para mulheres \\ e crianças
}

Beatriz Macedo Coimbra dos Santos 1

Flavio Codeço Coelho 1

Margaret Armstrong 1

Valeria Saraceni 2

Cristina Lemos 2

\begin{abstract}
Recent data from the municipality of Rio de Janeiro, Brazil, shows a sharp drop in the number of reported occurrences of Zika during the summer of 2016/2017, compared to the previous summer. There is still a much higher incidence among women than men, almost certainly due to sexual transmission. An unexpected feature of the new data is that there are proportionally far more cases affecting children under 15 months than older age classes. By comparing incidence rates in 2016/2017 and 2015/2016, we were able to deduce the proportion of reported cases affecting men and women, and verify that gender disparity is still present. Women and children are still risk groups for Zika infection, even during non-epidemic seasons.
\end{abstract}

Zika Virus; Women; Child; Incidence

\section{Correspondence}

B. M. C. Santos

Fundação Getulio Vargas.

Praia de Botafogo 190, Rio de Janeiro, RJ 22250-900, Brasil.

beatrizmcoimbra@outlook.com

1 Fundação Getulio Vargas, Rio de Janeiro, Brasil.

2 Secretaria Municipal de Saúde, Rio de Janeiro, Brasil. 


\section{Introduction}

Although in most Latin-American countries Zika is officially no longer an emergency public health issue, the threat remains far from over in places where it reached epidemic levels during the 2015/2016 outbreak. Brazil went through the last summer without any significant outbreaks. As Cohen ${ }^{1}$ pointed out, this was probably due to herd immunity. However, in Rio de Janeiro there were still enough cases (897) to allow for incidences in each age bracket to be compared with those of the previous year (Figure 1). Striking features of this data are: (1) there were 2.71 times more cases affecting women in the sexually active age bracket than men; (2) there was a peak of cases affecting infants up to 15 months old, who are only now contracting Zika, possibly as a result of women having a higher risk of infection.

Reports from Brazil and Colombia 2,3 pointed to up to three times more cases affecting women than men during the 2015/2016 epidemic. At the time their results were published, it was suggested that the excess of female cases could be explained by the state of alert concerning the association between Zika and microcephaly, with increased attention given to female cases by health professionals 4 . This question makes it all the more important to carry out new analyses confirming or rejecting the hypothesis of intrinsically higher risk to women, which is supported by many studies 5,6,7. The absence of an epidemic in the summer of 2016/2017 came with an understandable sense of relief. Beyond that relief, it can be seen as a unique opportunity - with no mass fear on the part of women and no specific health programs monitoring women for Zika - to verify whether or not Zika incidence is gender-biased.

We start by dissecting the incidence rate data from both years according to age, gender and mode of transmission, and then proceed to test whether the incidences in women and infants in the nonepidemic period were higher than expected.

\section{Methods}

The dataset of Zika cases used in this study was obtained from SINAN (the Brazilian national registry for diseases with mandatory reporting), through the Infodengue project 8 . We analyzed all reported Zika and dengue cases which took place in the city of Rio de Janeiro between January 2015 and July

Figure 1

Zika cases in Rio de Janeiro, Brazil, January 2015 to August 2016.

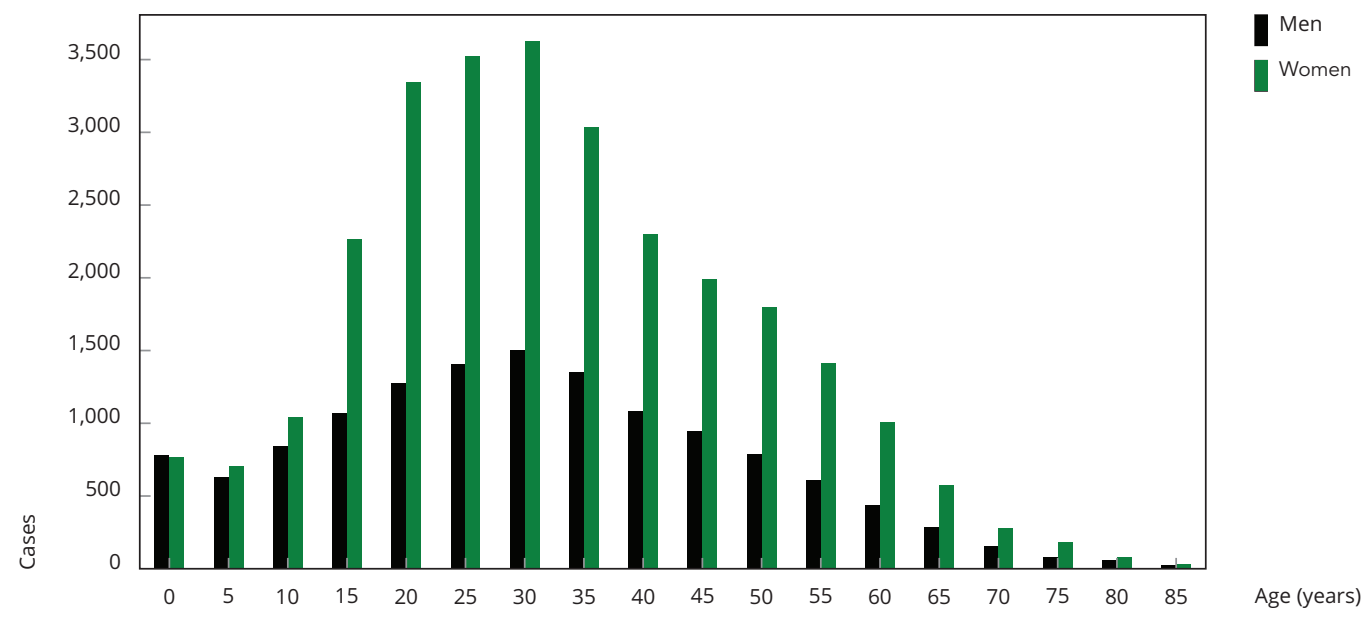


2017. The incidence of dengue was used as a control, since it has the same vectoral transmission mechanism as Zika, but is not sexually transmissible.

In order to better understand the effects of the Zika virus (ZIKV), we also employed a dataset from the Brazilian Institute of Geography and Statistics (IBGE) containing forecasts of population size for Rio de Janeiro, and then analyzed the incidence of Zika in both the epidemic and nonepidemic periods.

For this analysis, the epidemic and post-epidemic periods were separated. The period from January 2015 up to August 2016 was designated year 1, and the period from September 2016 up to July 2017 was designated year 2 .

Let $\alpha_{1}$ and $\alpha_{2}$ be the proportions of susceptible people who were infected by ZIKV via mosquito bite during years 1 and 2, respectively. We assume that these proportions are the same for men and women.

Let $\beta_{M}$ and $\beta_{W}$ be the proportions of reported Zika cases for men and women, respectively. Therefore, proportions of unreported cases are $\left(1-\beta_{M}\right)$ and $\left(1-\beta_{W}\right)$. We assume that both symptomatic and asymptomatic patients transmit the ZIKV 9 , and also that the reporting rates for men and women did not change from one year to the next. These rates are shown in Tables 1 and 2.

Other rates can be expressed using the terms presented above. For example, the product $\alpha_{1} \beta_{M}$ is the proportion of vectorially transmitted male Zika cases reported during year 1 . As we know that men can only contract Zika via mosquito bites, we consider all male cases as originating from vector transmission. The reporting rate for males $\left(\beta_{M}\right)$ is known to be approximately 0.110 and assuming that the whole population was susceptible to Zika during year 1, we thus have:

$$
\alpha_{1} \beta_{M}=\frac{m}{M}
$$

where $m$ is the total number of reported male cases and $M$ is the total male population. Therefore, rate $\alpha_{1}$ can be defined as follows:

$$
\alpha_{1}=\frac{m}{M \times \beta_{M}}
$$

by applying the data into the equation above, we obtain $\alpha_{1} \approx 0.044$, meaning that the total number of male Zika cases (including unreported cases) is estimated at 133,110.

\section{Table 1}

\begin{tabular}{|c|c|c|c|c|c|}
\hline & \multicolumn{2}{|c|}{ Vector transmission } & \multicolumn{2}{|c|}{ Sexual transmission } & \multirow[t]{2}{*}{ Still susceptible } \\
\hline & Reported & Unreported & Reported & Unreported & \\
\hline Men & $a_{1} \beta_{M}$ & $a_{1}\left(1-\beta_{M}\right)$ & - & - & $\left(1-a_{1}\right)$ \\
\hline Women & $a_{1} \beta_{W}$ & $a_{1}\left(1-\beta_{W}\right)$ & $y_{1} \beta_{W}\left(1-a_{1}\right)$ & $y_{1}\left(1-\beta_{W}\right)\left(1-a_{1}\right)$ & $\left(1-a_{1}\right)\left(1-y_{1}\right)$ \\
\hline
\end{tabular}

Proportions of infected by each transmission route divided by sex and age group in 2016

Table 2

\begin{tabular}{|c|c|c|c|c|c|}
\hline & \multicolumn{2}{|c|}{ Vector transmission } & \multicolumn{2}{|c|}{ Sexual transmission } & \multirow[t]{2}{*}{ Still susceptible } \\
\hline & Reported & Unreported & Reported & Unreported & \\
\hline Infants & $a_{2} \beta_{M}$ & $a_{2}\left(1-\beta_{M}\right)$ & - & - & $\left(1-a_{2}\right)$ \\
\hline Men & $a_{2} \beta_{M}$ & $a_{2}\left(1-\beta_{M}\right)$ & - & - & $\left(1-a_{2}\right)$ \\
\hline Women & $a_{2} \beta_{W}$ & $a_{2}\left(1-\beta_{W}\right)$ & $\gamma_{2} \beta_{w}\left(1-a_{2}\right)$ & $\gamma_{2}\left(1-\beta_{W}\right)\left(1-a_{2}\right)$ & $\left(1-a_{2}\right)\left(1-y_{2}\right)$ \\
\hline
\end{tabular}

Proportions of infected by each transmission route divided by sex and age group in 2017 . 
The proportion of female Zika cases reported during year $1\left(\beta_{W}\right)$ is known to be approximately 0.1210 .

Let $\gamma_{1}$ and $\gamma_{2}$ be the proportions of susceptible women between 15 and 60 years old (hereby defined as the sexually active age bracket) who contracted Zika through sexual transmission in year 1 and 2 , respectively. As we consider sexual transmission only when analyzing female cases, the product $\gamma_{1} \beta_{W}\left(1-\alpha_{1}\right)$ is the proportion of reported, sexually contracted, female Zika cases for year 1, and the calculation with respect to year 2 is analogous. We assume sexual transmission from women to men to be insignificant 11 .

To evaluate the excess of female cases in the sexually active age bracket, we applied the chi-squared test to the number of cases affecting men and women between 15 and 60 years old.

Susceptible populations were different in year 1 and 2: after the first epidemic, we assume people who contracted Zika then became immune to it. Therefore, to determine year 2's susceptible population size, year 1's Zika cases were subtracted from the total population. Thus we have the following scheme, denoted by $S_{i}^{j}$ (the number of susceptible people from the group $j$ in year $i$ ):

$$
\left\{\begin{array}{l}
S_{2}^{I}=\left(1-\alpha_{1}\right) S_{1}^{I} \\
S_{2}^{M}=\left(1-\alpha_{1}\right) S_{1}^{M} \\
S_{2}^{W}=\left(1-\alpha_{1}\right)\left(1-\gamma_{1}\right) S_{1}^{W}
\end{array}\right.
$$

where the groups $I, M$ and $W$ correspond, respectively, to infants, men and women.

Let $\alpha_{2}$ be the proportion of susceptible people who got Zika via mosquito bite during year 2 . Assuming that this proportion is the same for all age groups, and focusing on the men group (who are not at risk of sexual transmission), we have the product $\alpha_{2} \beta_{M}$ as year 2's proportion of reported masculine cases. With that knowledge, $\alpha_{2}$ can be calculated by dividing the number of masculine cases during year 2 by the susceptible masculine population in the same year multiplied by $\beta_{W}$. The number of susceptible men in year 2 was obtained from year 1 , weighted by the rate $\left(1-\alpha_{1}\right)$, which represents the proportion of susceptible people in this group.

\section{Results}

Figure 2 shows the incidence timeseries for both periods. Clearly there was no outbreak in Rio de Janeiro during year 2, most likely due to herd immunity built up over the previous year. Still, transmission never stopped completely after the 2015/2016 epidemic. For this analysis, we assumed that in the post-epidemic period of 2016/2017, the risk of getting Zika through the vectoral route was independent of gender and age. Thus, the rate $\alpha_{2}-$ the proportion of susceptible people who got Zika via mosquito bite in year 2 - should be the same for children and men (Table 2).

Figure 3 shows the age distribution Zika cases per week for women and men within Rio de Janeiro in year 2 (September 2016 to July 2017). Women between 15 and 60 years of age had 3-4 times more occurrences than men in the same age bracket ( 474 women cases vs. 174 men cases). A similar pattern was observed in the previous epidemic year (Figure 1). A chi-squared test - with the null hypothesis stating no relation between being a sexually active women and getting Zika during the non-epidemic period - confirmed a higher than expected risk of Zika for the female population within the sexually active age bracket (Table 3 ) ( $<<10-27 ; \chi^{2}=115.77$, and one degree of freedom).

When calculating this rate $\left(\alpha_{2}\right)$ from the number of masculine cases, we obtain $\alpha_{2} \approx 0.001$. However, if we perform the same calculation based on occurrences affecting children from 0 to 4 years old, we get a result of approximately 0.003 . This means that children in fact have approximately a 3 times higher risk of Zika infection, compared to the adult male group.

A chi-squared test confirmed higher than expected incidence rate of Zika for children younger than 4 years (Tables 4 and 5). The expected numbers returned by this contingency table are very similar to the ones obtained from the rates shown in Tables 6 and 7. 


\section{Figure 2}

Comparison between the number of Zika cases in years 1 and 2 . Both series start on epidemiological week 27, ending on epidemiological week 26 of the following year.

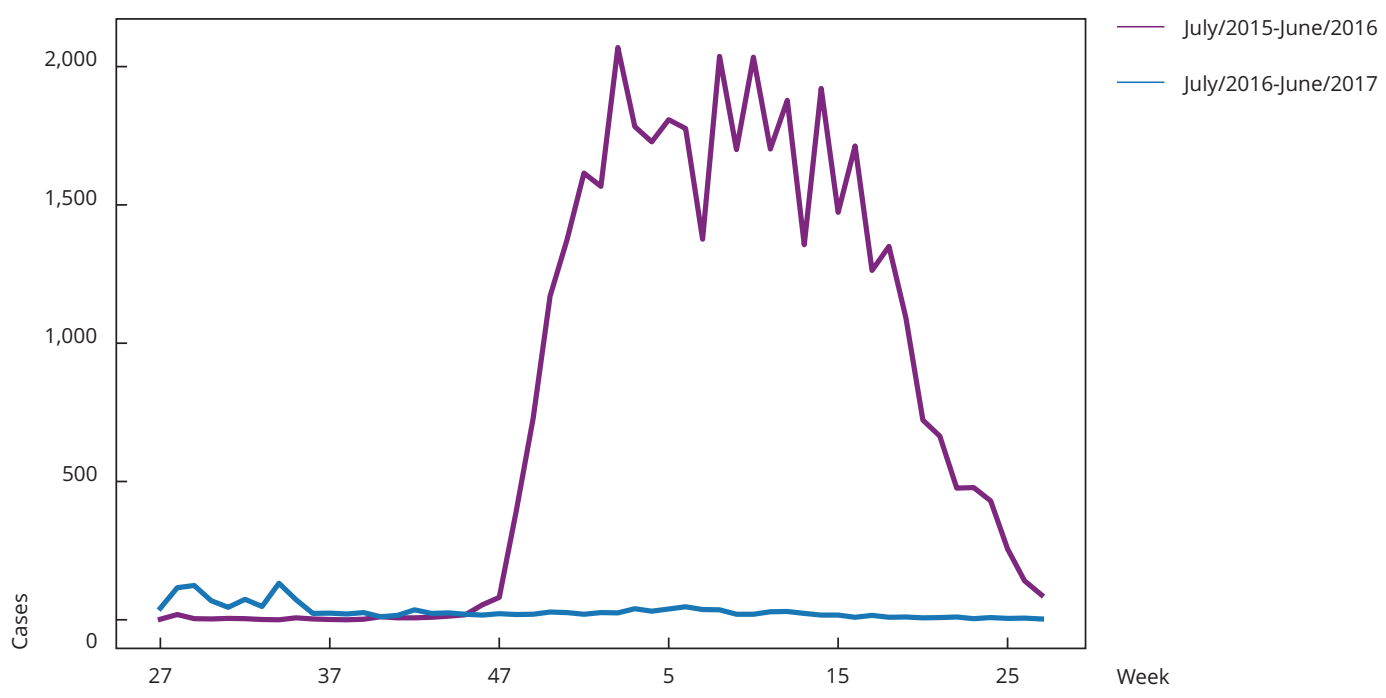

Figure 3

Zika cases in Rio de Janeiro, Brazil, September 2016 to July 2017.

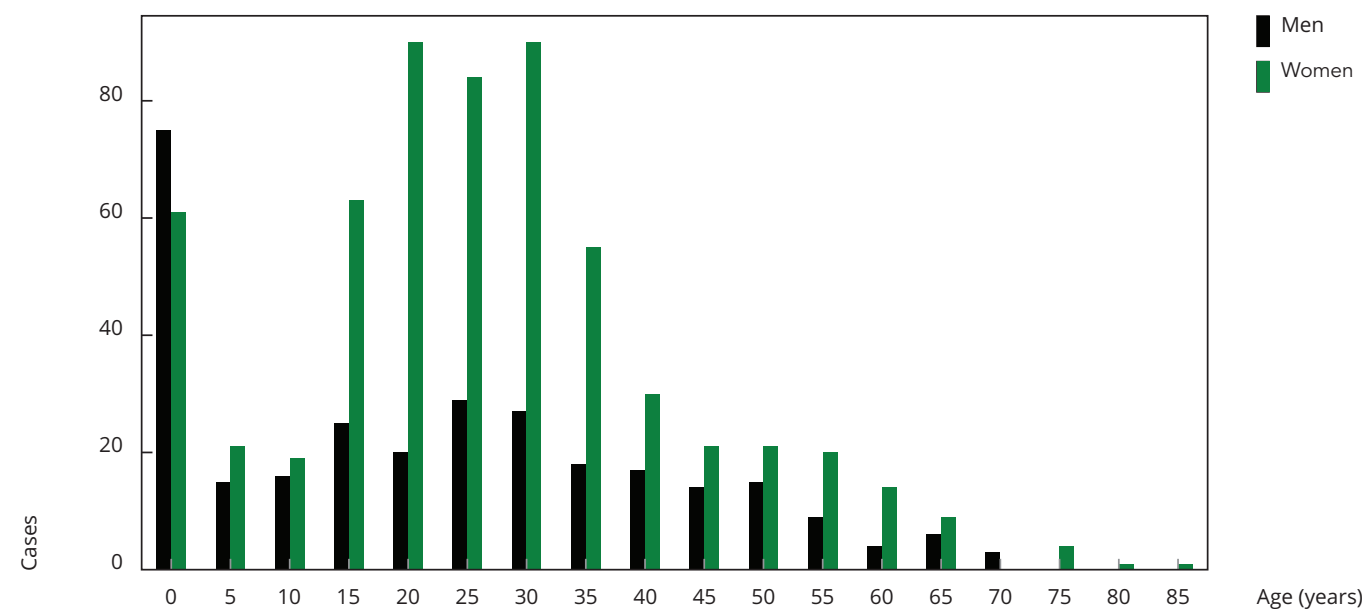

Figure 4 shows a histogram of both sexes in this age bracket, with the majority of occurrences affecting children under 15 months of age and thus born after the end of the previous epidemic (99 cases, from a total of 136 in the whole age group). 
Table 3

Observed contingency table for the sexually active population (15-60 years old). Rio de Janeiro, Brazil, in 2017.

\begin{tabular}{lcc}
\hline & Zika cases & No Zika \\
\hline Men & 174 & $2,011,783$ \\
Adults & 474 & $2,175,157$ \\
\hline
\end{tabular}

Table 4

Observed number of cases in children (0-4 years old) and adults for the population of Rio de Janeiro, Brazil, 2016/2017.

\begin{tabular}{lcc}
\hline & Zika cases & No Zika \\
\hline Children (0-4) & 136 & 337,191 \\
Adults & 761 & $6,063,867$ \\
\hline
\end{tabular}

\section{Table 5}

Expected number of cases in children (0-4 years old) and adults for the population of Rio de Janeiro, Brazil, assuming equal infection rates in both groups, 2016/2017.

\begin{tabular}{lcc}
\hline & Zika cases & No Zika \\
\hline Children (0-4) & 47 & 337,279 \\
Adults & 849 & $6,063,778$ \\
\hline
\end{tabular}

Table 6

Results for Table 1: numbers for the epidemic year.

\begin{tabular}{lccccc}
\hline & \multicolumn{2}{c}{ Vector transmission } & \multicolumn{2}{c}{ Sexual transmission } & Still susceptible \\
& Reported & Unreported & Reported & Unreported & \\
\hline Men & $0.44 \%(13,311)$ & $4.00 \%(119,799)$ & - & - & $95.55 \%(2,860,907)$ \\
Women & $0.53 \%(18,098)$ & $3.91 \%(132,724)$ & $0.60 \%(20,356)$ & $4.40 \%(149,282)$ & $90.55 \%(3,071,963)$ \\
\hline
\end{tabular}

Note: percentages of the total susceptible population which contracted Zika or remained susceptible to it. Raw number of case in parenthesis, based on our estimates for the mentioned rates.

Table 7

Results for Table 2: numbers for the non-epidemic period.

\begin{tabular}{|c|c|c|c|c|c|}
\hline & \multicolumn{2}{|c|}{ Vector transmission } & \multicolumn{2}{|c|}{ Sexual transmission } & \multirow[t]{2}{*}{ Still susceptible } \\
\hline & Reported & Unreported & Reported & Unreported & \\
\hline Infants & $0.012 \%(40)$ & $0.090 \%(296)$ & - & - & $99.897 \%(328,648)$ \\
\hline Men & $0.010 \%(275)$ & $0.092 \%(2,482)$ & - & - & $99.897 \%(2,690,656)$ \\
\hline Women & $0.012 \%$ (358) & $0.090 \%(2,630)$ & $0.013 \%$ (393) & $0.098 \%(2,882)$ & $99.785 \%(2,912,657)$ \\
\hline
\end{tabular}

Note: percentages of the total susceptible population which got Zika or remained susceptible. In parenthesis are the raw number of cases, based on our estimates for the mentioned rates. 


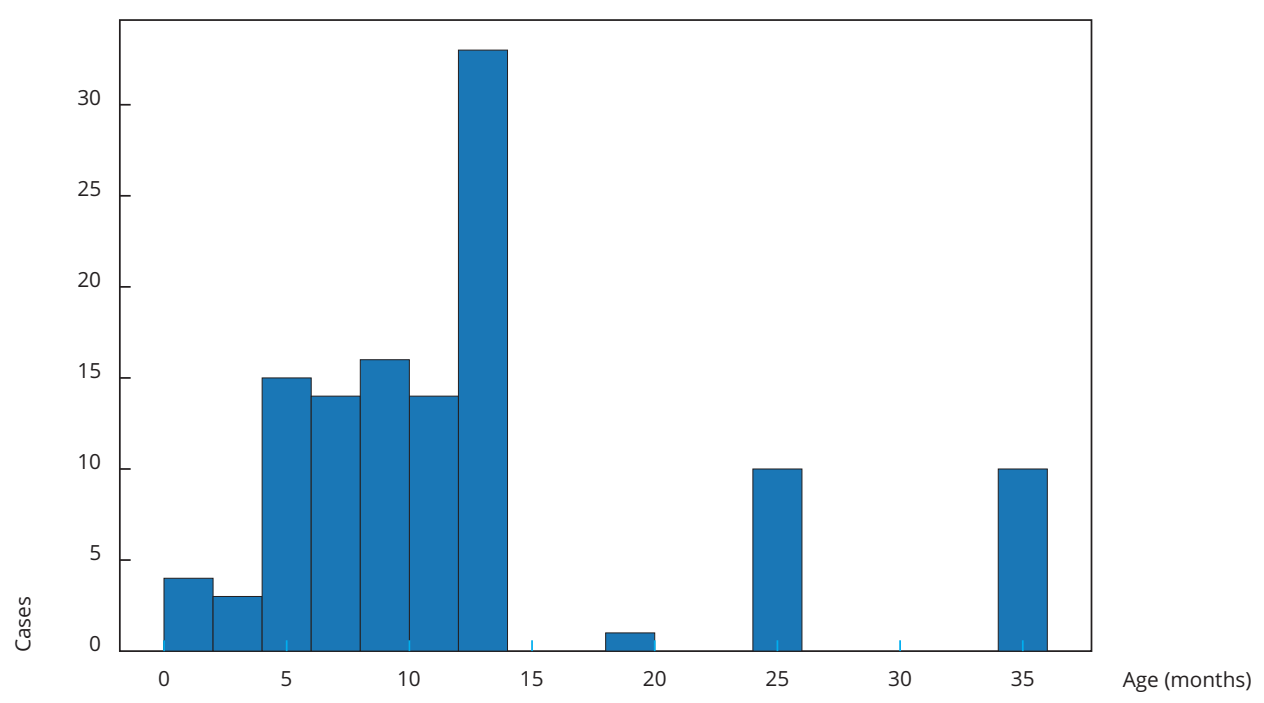

Finally, to rule out the possibility of the age-related incidence patterns being caused by differential exposure to mosquito bites, Figure 5 shows the age-distributed incidence of dengue for 2016/2017 (year 2).

\section{Discussion}

The difference in incidence between women and men in the 15-60 years age bracket confirms our previous results ${ }^{3}$ and those from Colombia 2 . It suggests a strong contribution of the sexual transmission route even during non-epidemic periods. The age bracket within which the effect is present is more sharply delimited, possibly due to the reduced intensity of vector transmission in the 2016/2017 dataset. A more intense vectoral transmission would tend to attenuate incidence differences between age classes specifically infected by mosquitoes and the sexually active age group in general.

Here we should note that external effects such as increased female reporting due to the emergency status of Zika are not likely to have played a role in the summer of 2016/2017. The comparison between age-distributed Zika incidence after the last epidemic in Rio de Janeiro and that of dengue (for the same period and place) is also interesting: the dengue epidemic showed a very small gender bias - probably due to the weight of severe cases, since in the 20-59 years old age bracket it affects much more women than men 12. If the explanation for ZIKV's apparent gender bias involved the diagnostic-seeking behavior of women, we would see significant impacts in dengue reporting rates for women as well, as both diseases have very similar clinical manifestations.

We cannot rule out the contribution of higher underreporting of male cases as a consequence of differences in health-seeking behavior of men and women; this is a possible explanation for the observed difference in attack rates. When comparing dengue and Zika incidence at the same time and place it is clear, however, that any Zika-unrelated effect is relatively small.

Unlike the age distribution of cases reported during 2015/2016, in year 2 there is an excess of occurrences affecting under 4-year-old children of both sexes (Figure 4). The majority of these cases affected children with less than 15 months of age. Due to the low number of cases and the lack of 
Figure 5

Dengue cases in Rio de Janeiro, Brazil, September 2016 to July 2017.

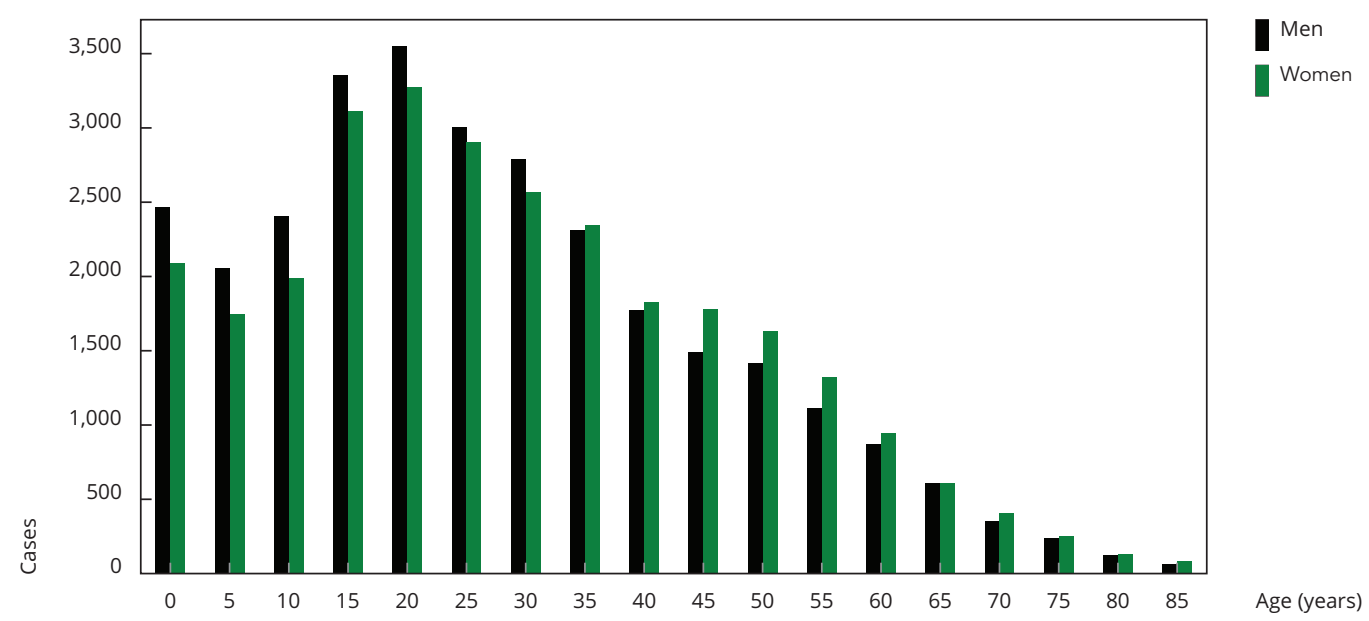

laboratory confirmations we cannot fully explain this phenomenon. However, we hypothesize that children of this age spend most of their time in the presence of women of reproductive age in households where the mosquito is ubiquitous. Thus, they may have been infected by mosquitoes which bit their mothers or care-givers at the day-care or pre-schools. The data nevertheless highlights potential risks of Zika for young children in a post-epidemic setting.

\section{Conclusions}

Zika remains a serious threat, especially to women and young children. There is still a great deal of uncertainty about the infectious period for sexual transmission in males. This dataset shows, unequivocally, that even during non-epidemic periods sexual transmission continues to be important, leading to an almost 4 times higher risk of infection in women vs. men. The excess in occurrences affecting women will continue to influence the risk of infants contracting the disease, leading to varying degrees of neurological damage: non-microcephalic Zika babies may still display milder but not necessarily less important issues such as macular atrophy 13 , congenital contractures 14 and various neurological sequelae.

Our main conclusions are that the protection of women against Zika must be redoubled in countries with ongoing transmission, and that more detailed studies should be funded to help answer the open questions about long-term effects of sexual transmission to the potential endemization of Zika and the consequent increase of the disease's public health burden. 


\section{Contributors}

B. M. C. Santos participated in study design, data analysis and writing. F. C. Coelho and M. Armstrong participated in data analysis and writing. V. Saraceni and C. Lemos analyzed data. All authors reviewed and approved the final version of the paper.

\section{Acknowledgments}

We thank the Infodengue project for the data used in this study.

\section{References}

1. Cohen J. Where has all the Zika gone? Science 2017; 357:631-2.

2. Pacheco O, Beltrán M, Nelson CA, Valencia D, Tolosa N, Farr SL, et al. Zika virus disease in colombia: preliminary report. N Engl J Med 2016; [Epub ahead of print].

3. Coelho FC, Durovni B, Saraceni V, Lemos C, Codeco CT, Camargo S, et al. Higher incidence of Zika in adult women than adult men in Rio de Janeiro suggests a significant contribution of sexual transmission from men to women. Int J Infect Dis 2016; 51:128-32.

4. Maxian O, Neufeld A, Talis EJ, Childs LM, Blackwood JC. Zika virus dynamics: when does sexual transmission matter? Epidemics 2017; 21:48-55.

5. Hamer DH, Wilson ME, Jean J, Chen LH. Epidemiology, prevention, and potential future treatments of sexually transmitted Zika virus infection. Curr Infect Dis Rep 2017; 19:16.

6. Possas C, Brasil P, Marzochi MC, Tanuri A, Martins RM, Marques ET, et al. Zika puzzle in Brazil: peculiar conditions of viral introduction and dissemination-a review. Mem Inst Oswaldo Cruz 2017; 112:319-27.

7. D'Ortenzio E, Matheron S, de Lamballerie X, Hubert B, Piorkowski G, Maquart M, et al. Evidence of sexual transmission of Zika virus. $\mathrm{N}$ Engl J Med 2016; 374:2195-8.

8. Codeco C, Cruz O, Riback TI, Degener CM, Gomes MF, Villela D, et al. Infodengue: a nowcasting system for the surveillance of dengue fever transmission. bioRxiv 2016; 046193.

9. Fréour T, Mirallié S, Hubert B, Splingart C, Barrière $P$, Maquart M, et al. Sexual transmission of Zika virus in an entirely asymptomatic couple returning from a Zika epidemic area, France, april 2016. Euro Surveill 2016; 21(23).

10. Bastos MM. Modelagem probabilística da dinâmica da Zika usando modelos hierárquicos bayesianos [Masters Thesis]. Rio de Janeiro: Escola de Matemática Aplicada, Fundação Getúlio Vargas; 2018.

11. Davidson A, Slavinski S, Komoto K, Rakeman J, Weiss D. Suspected female-to-male sexual transmission of Zika virus: New York City, 2016. MMWR Morb Mortal Wkly Rep 2016; 65:716-7.

12. Guerra-Silveira F, Abad-Franch F. Sex bias in infectious disease epidemiology: patterns and processes. PLoS One 2013; 8:e62390.

13. Ventura CV, Maia M, Bravo-Filho V, Góis AL, Belfort R. Zika virus in Brazil and macular atrophy in a child with microcephaly. Lancet 2016; 387:228.

14. Moore CA, Staples JE, Dobyns WB, Pessoa A, Ventura CV, Da Fonseca EB, et al. Characterizing the pattern of anomalies in congenital Zika syndrome for pediatric clinicians. JAMA Pediatr 2017; 171:288-95. 


\section{Resumo}

Dados recentes do Município de Rio de Janeiro, Brasil, mostram uma queda importante na notificação de casos de Zika no verão de 2016/2017, comparado ao verão anterior. A incidência ainda é muito mais alta em mulheres do que em homens, quase certamente em função da transmissão sexual. Uma característica inesperada dos novos dados é que, proporcionalmente, há muito mais casos em crianças abaixo dos 15 meses de idade, quando comparadas àquelas das faixas mais velhas. Ao comparar as taxas de incidência em 2016/2017e 2015/2016, conseguimos deduzir a proporção de casos notificados em homens e mulheres e confirmar que a disparidade de gênero ainda existe. As mulheres e crianças ainda são grupos de risco para a infecção pelo vírus Zika, mesmo durante períodos não epidêmicos.

Zika Virus; Mulheres; Criança; Incidência

\section{Resumen}

Datos recientes del municipio de Río de Janeiro, Brasil, muestran un descenso importante en la notificación de casos de Zika durante el verano de 2016/2017, comparado con el verano anterior. La incidencia todavía es mucho más alta en mujeres que en hombres, casi con seguridad debido a la transmisión sexual. Una característica inesperada de los nuevos datos es que, proporcionalmente, hay muchos más casos en niños por debajo de los 15 meses de edad, cuando se comparan con aquellas franjas con edad superior. Al comparar las tasas de incidencia en 2016/2017 y 2015/2016, conseguimos deducir la proporción de casos notificados en hombres y mujeres y confirmar que la disparidad de género todavía existe. Las mujeres $y$ niños todavía son grupos de riesgo para la infección por el virus Zika, incluso durante períodos no epidémicos.

Virus Zika; Mujeres; Niño; Incidencia
Submitted on 06/Mar/2018

Final version resubmitted on $28 / \mathrm{Jul} / 2018$ Approved on 29/Aug/2018 